Milestone M4FT-13LL0807071: International Collaboration - Radionuclide Interactions and Transport in Geologic Repository Environments \# $\mathrm{Pu}$ Interaction with Bentonite

J. D. Begg, M. Zavarin, A. B. Kersting

November 14, 2013 
This document was prepared as an account of work sponsored by an agency of the United States government. Neither the United States government nor Lawrence Livermore National Security, LLC, nor any of their employees makes any warranty, expressed or implied, or assumes any legal liability or responsibility for the accuracy, completeness, or usefulness of any information, apparatus, product, or process disclosed, or represents that its use would not infringe privately owned rights. Reference herein to any specific commercial product, process, or service by trade name, trademark, manufacturer, or otherwise does not necessarily constitute or imply its endorsement, recommendation, or favoring by the United States government or Lawrence Livermore National Security, LLC. The views and opinions of authors expressed herein do not necessarily state or reflect those of the United States government or Lawrence Livermore National Security, LLC, and shall not be used for advertising or product endorsement purposes.

This work performed under the auspices of the U.S. Department of Energy by Lawrence Livermore National Laboratory under Contract DE-AC52-07NA27344. 


\title{
Milestone M4FT-13LL0807071: International Collaboration - Radionuclide Interactions and Transport in Geologic Repository Environments - Pu Interaction with Bentonite
}

\author{
J.D. Begg, M. Zavarin, A.B. Kersting \\ Glenn T. Seaborg Institute, Physical \& Life Sciences, Lawrence Livermore National Laboratory, 7000 \\ East Avenue, Livermore, CA 94550, USA
}

\section{INTRODUCTION}

The focus of this project is to investigate radionuclide interactions with natural and engineered materials, specifically the mineral bentonite that will be used in EU repositories and possibly in US high-level waste repository designs. These experiments are designed to develop a mechanistic understanding of $\mathrm{Pu}$ interactions with representative mineral substrates under granitic chemical conditions. The sorption/desorption experiments cover a large range of $\mathrm{Pu}$ concentrations and will be compared to sorption/desorption experiment with montmorillonite. The experiments are being coordinated with the Colloid Formation and Migration (CFM) international project led by Karlsruhe Institute of Technology and located at the Grimsel Test Site underground research laboratory in Switzerland. Experiments will be completed by 8/15/2014. Milestone M4FT-13LL0807071 is a progress report on this effort. The research is addressing the following FEPs/needs identified in the R\&D Roadmap: 2.2.09.05 - radionuclide speciation and solubility in host rock; 2.2.09.55 - sorption of dissolved radionuclides in host rock; 2.2.09.59 - colloidal transport in host rock.

The bentonite clay used in these experiments was FEBEX bentonite received from the National Cooperative for the Disposal of Radioactive Waste (Nagra), Switzerland that plans to use the clay as a backfill material in its nuclear waste repositories. This clay has been characterized previously and comprised $93 \pm 3 \%$ montmorillonite, $2 \pm 0.5 \%$ quartz, $2 \pm 1 \%$ potassium feldspars, $1 \pm 0.7 \%$ plagioclase, $2 \pm 0.2 \%$ cristobalite, $1 \pm 0.7 \%$ calcite and $1.5 \pm 0.1 \%$ rhyodacitic rock $^{1}$. Prior to use the clay was Nahomoionized, lightly ground in a mortar and pestle and the resulting material sieved (size fraction $<63$ $\mu \mathrm{m})$. The surface area of the clay as used in these experiments was $25.2 \pm 1.0 \mathrm{~m}^{2} \mathrm{~g}^{-1}$. In order to ensure consistency with previous montmorillonite adsorption work, experiments were performed in $0.7 \mathrm{mM}$ $\mathrm{NaHCO}_{3}, 5 \mathrm{mM} \mathrm{NaCl}$ buffer solution with a solid: solution ratio of $1 \mathrm{~g} \mathrm{~L}^{-1}$. All experiments were performed under ambient atmospheric conditions.

\begin{abstract}
ADSORPTION
To compare the rate of adsorption of $\mathrm{Pu}(\mathrm{V})$ on bentonite to the rate of $\mathrm{Pu}(\mathrm{V})$ adsorption on montmorillonite at $\mathrm{pH} 8$, a time series experiment was performed in triplicate with an initial concentration of $10^{-10} \mathrm{~mol} \mathrm{~L}{ }^{-1} \mathrm{Pu}(\mathrm{V})$. The results of this experiment are shown in Figure 1. Here the adsorption of Pu to bentonite is plotted as a function of time along with previously published data for the adsorption of $\mathrm{Pu}(\mathrm{V})$ to montmorillonite ${ }^{2}$. The log surface area normalized apparent rate of sorption for bentonite was $-3.4 \mathrm{~L}$ $\mathrm{m}^{-2} \mathrm{~h}^{-1}$ as compared to the value of $-2.8 \mathrm{~L} \mathrm{~m}^{-2} \mathrm{~h}^{-1}$ for montmorillonite. This similarity in the rate of $\mathrm{Pu}(\mathrm{V})$
\end{abstract}


adsorption to both clays suggests that the large component of montmorillonite in the bentonite clay is primarily responsible for the uptake of $\mathrm{Pu}(\mathrm{V})$ from the aqueous phase.

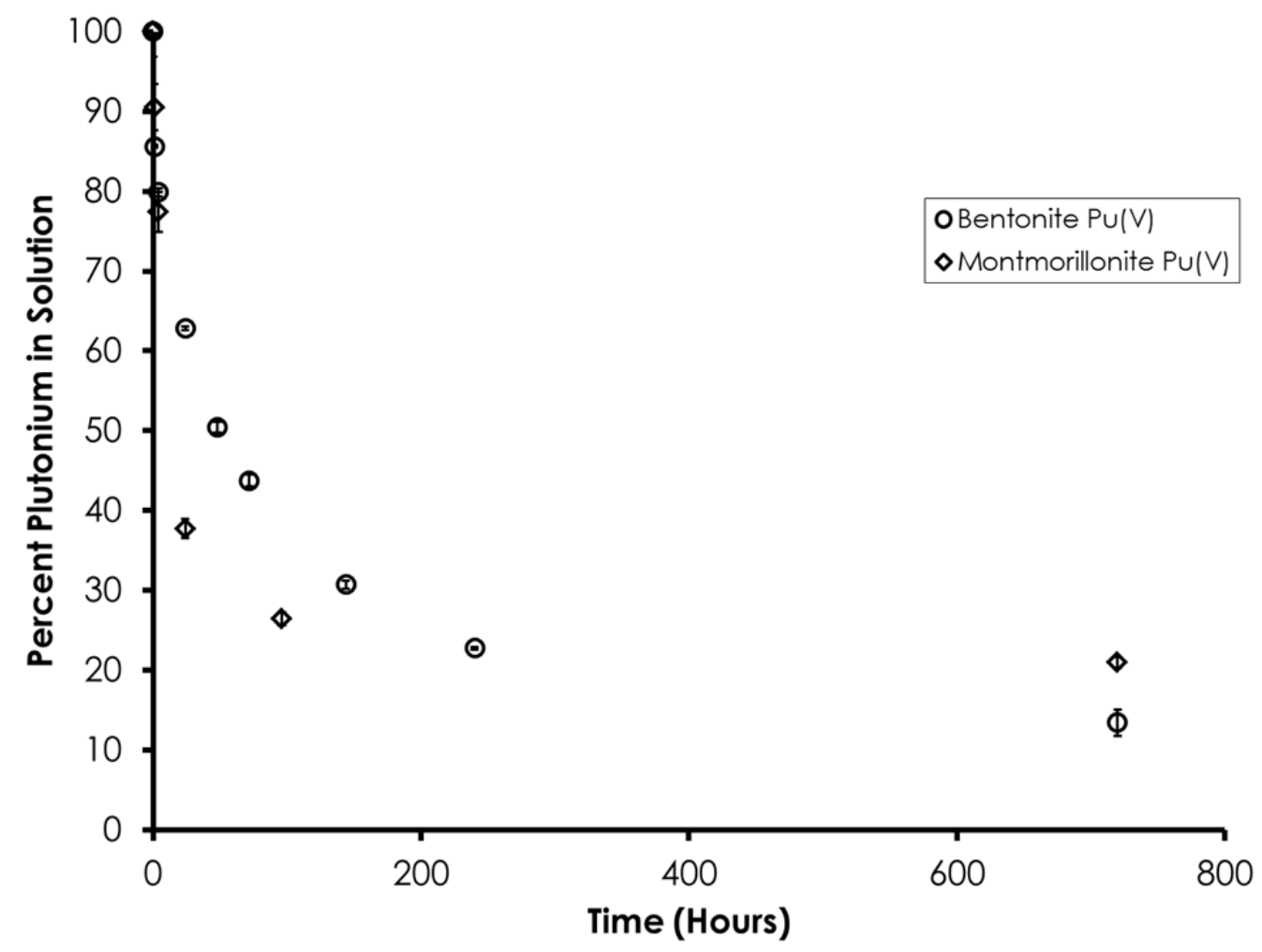

Figure 1 Sorption of $\mathrm{Pu}(\mathrm{V})$ to FEBEX bentonite (circles) and SWy-1 Na-montmorillonite (diamonds) plotted as percentage of $\mathrm{Pu}$ removed from solution vs. time. Initial Pu concentrations were $10^{-10} \mathrm{M}$ for bentonite and $10^{-9} \mathrm{M}$ for montmorillonite. Error bars for bentonite are $1 \sigma$ of triplicate experiments and are $1 \sigma$ values calculated from parallel quadruplicate experiments for montmorillonite.

A $\mathrm{Pu}(\mathrm{IV})$ adsorption isotherm was performed with bentonite at $\mathrm{pH}$ 8. Previous work with $\mathrm{Pu}(\mathrm{IV})$ and $\mathrm{Pu}(\mathrm{V})$ adsorption to montmorillonite has shown that $\mathrm{Pu}(\mathrm{V})$ adsorption behavior will converge with that of $\mathrm{Pu}(\mathrm{IV})$ over sufficient timescales ${ }^{2,3}$. The Pu adsorption experiment was performed with initial $\mathrm{Pu}(\mathrm{IV})$ concentrations $\left([\mathrm{Pu}]_{\text {initial }}\right)$ ranging from $10^{-7}-10^{-16} \mathrm{~mol} \mathrm{~L}^{-1}$. As previous work has highlighted the need for long equilibration periods when performing Pu adsorption studies, $\mathrm{Pu}(\mathrm{IV})$ was equilibrated for 120 days in these experiments ${ }^{2,4}$. Pu in solution was measured using liquid scintillation counting (LSC) for experiments with $[\mathrm{Pu}]_{\text {initial }} 10^{-7}-10^{-11} \mathrm{~mol} \mathrm{~L}^{-1}$ and at the Center for Accelerator Mass Spectrometry (CAMS) at LLNL for experiments with $[\mathrm{Pu}]_{\text {initial }} 10^{-11}-10^{-16} \mathrm{~mol} \mathrm{~L}^{-1}$.

The $\mathrm{Pu}(\mathrm{IV})$ sorption isotherm is shown in Figure 2. $\mathrm{Pu}(\mathrm{IV})$ sorption was broadly linear at $[\mathrm{Pu}]_{\text {initial }}$ ranging from $10^{-7} \mathrm{~mol} \mathrm{~L}^{-1}$ to $10^{-16} \mathrm{~mol} \mathrm{~L}^{-1}$ after 120 days' equilibration. The slope of the plot of $\log [\mathrm{Pu}]$ in solution against $\log [\mathrm{Pu}]$ on solid was $1.06\left(\mathrm{R}^{2}\right.$ 0.998). The $\mathrm{K}_{\mathrm{d}}$ values ranged from $21000-79000 \mathrm{~mL} \mathrm{~g}^{-1}$. Also plotted in Figure 2 is the equivalent $\mathrm{Pu}(\mathrm{IV})$ montmorillonite adsorption isotherm for $[\mathrm{Pu}]_{\text {initial }} 10^{-7} \mathrm{~mol} \mathrm{~L}^{-1}$ 
- $10^{-13} \mathrm{~mol} \mathrm{~L}^{-1}$ following 30 days' equilibration. The slope of the plot of $\log [\mathrm{Pu}]$ in solution against $\log [\mathrm{Pu}]$ on solid for montmorillonite was $1.04\left(\mathrm{R}^{2}\right.$ 0.997) while $\mathrm{K}_{\mathrm{d}}$ values ranged from $8900-27000 \mathrm{~mL}$ $\mathrm{g}^{-1}$. The similarity of the $\mathrm{Pu}(\mathrm{IV})$ bentonite and montmorillonite isotherms further suggests that the montmorillonite in the bentonite is largely responsible for controlling the adsorption of $\mathrm{Pu}$ in these experiments.

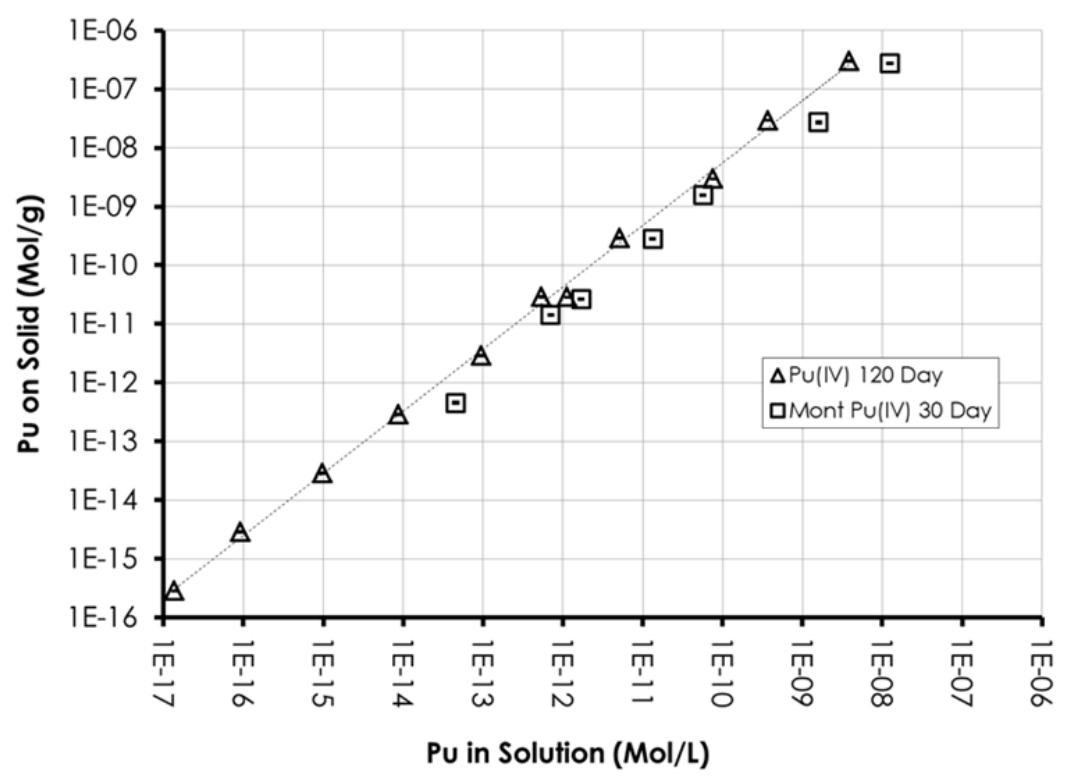

Figure 1120 day $\mathrm{Pu}(\mathrm{IV})$ sorption isotherm for FEBEX bentonite $\left(1 \mathrm{~g} \mathrm{~L}^{-1}\right.$; triangles) and 30 day $\mathrm{Pu}(\mathrm{IV})$ sorption isotherm for Na-montmorillonite $\left(1 \mathrm{~g} \mathrm{~L}^{-1}\right.$; squares) in $0.7 \mathrm{mM} \mathrm{NaHCO}, 5 \mathrm{mM}$ NaCl buffer solution at $\mathrm{pH} 8$.

\section{DESORPTION}

A flow-cell experiment was used to characterize Pu(IV) desorption from bentonite and to compare it with previously determined $\mathrm{Pu}(\mathrm{IV})$ - montmorillonite desorption behavior. Prior to the desorption step, $\mathrm{Pu}(\mathrm{IV})$ was equilibrated with bentonite at $\mathrm{pH} 8$ for 21 days. Desorption experiments were performed in a $20 \mathrm{~mL}$ stirred cell fitted with a $100 \mathrm{~nm}$ filter and a stir bar to ensure ideal mixing conditions. An aliquot of adsorption suspension was placed in the flow cell and atmosphere-equilibrated Pu-free $0.7 \mathrm{mM} \mathrm{NaHCO}$, $5 \mathrm{mM} \mathrm{NaCl}$ buffer solution at $\mathrm{pH} 8$ flowed through the cell at an initial rate of $0.4 \mathrm{~mL} / \mathrm{min}$ (average retention time of $\sim 50$ minutes). Effluent fractions were collected over time, acidified with $2 \% \mathrm{HNO}_{3}$ and Pu concentration determined via LSC. In order to evaluate the kinetics of the desorption process, the flow rate was changed approximately every 10 pore volumes to flow rates of $0.2,0.04$, and $0.02 \mathrm{~mL} \mathrm{~min}{ }^{-1}$.

The results from both the bentonite and the montmorillonite flow cell experiments at $\mathrm{pH} 8$ are shown in Figure 3. The results show that there is measurable desorption of Pu from bentonite over the duration of the flow cell experiment. In the first flow regime $\left(0.4 \mathrm{~mL} \mathrm{~min}^{-1}\right)$, differences between the two systems are likely due to poor mixing in the bentonite cell caused by a non-rotational stir bar. This was rectified after 
1.8 pore volumes. Further divergence between the two systems is also seen towards the end of the flow cell experiment $\left(0.04 \mathrm{~mL} \mathrm{~min}^{-1}\right)$. Nonetheless, the desorption profiles for bentonite and montmorillonite are very similar, indicating that, as with the adsorption experiments, the same processes are responsible for the desorption of Pu from the two clays.

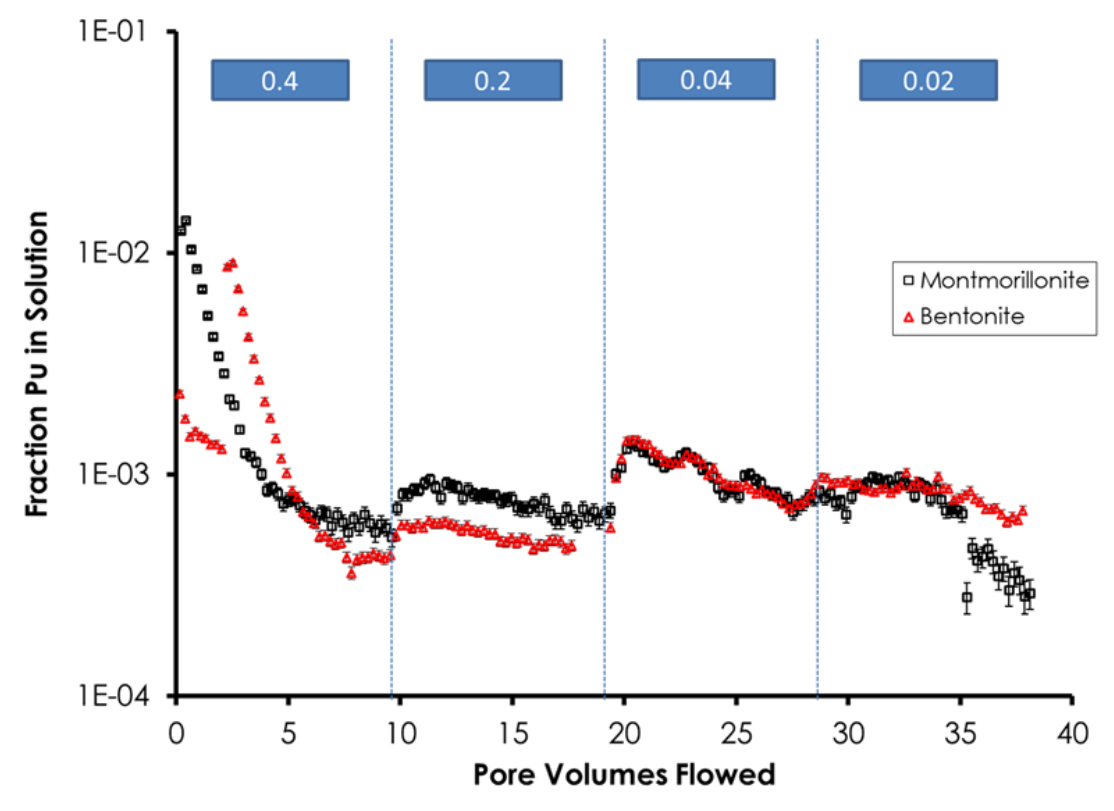

Figure 3 Results from Pu(IV) - montmorillonite (squares) and Pu(IV) - bentonite (triangles) desorption flow-cell experiments. Data points represent the fraction of the total system $\mathrm{Pu}$ in the collected effluent. Experiments performed in a $20 \mathrm{~mL}$ cell with $1 \mathrm{~g} \mathrm{~L}^{-}$clay at $\mathrm{pH} 8$. Montmorillonite experiments were spiked with $[\mathrm{Pu}]_{\text {initial }} 1 \times 10^{-10} \mathrm{M}$, bentonite experiments spiked with $[\mathrm{Pu}]_{\text {initial }} 3 \times$ $10^{-10}$ M. Influent solution was $\mathrm{Pu}$-free $0.7 \mathrm{mM} \mathrm{NaHCO}_{3}, 5 \mathrm{mM} \mathrm{NaCl}$ buffer. Influent flow rates were $0.4,0.2,0.04$ and $0.02 \mathrm{ml} \mathrm{min}^{-1}$ and are shown on the plot. Changes in flow rate are denoted by vertical dashed lines. Error bars based on propagation of $\% 2 s$ liquid scintillation counting uncertainties.

\section{SUMMARY}

From our work to date we can conclude that:

- Adsorption behavior of $\mathrm{Pu}(\mathrm{V})$ on bentonite is similar to montmorillonite suggesting that our understanding of the simple binary Pu-montmorillonite system can provide insight for the more complex multi-component mineralogy of bentonite clay.

- $\quad$ The $\mathrm{Pu}(\mathrm{IV})$ sorption isotherm for bentonite is broadly linear over a large range in $\mathrm{Pu}$ concentration ( $[\mathrm{Pu}]_{\text {initial }}$ ranging from $10^{-7} \mathrm{~mol} \mathrm{~L}^{-1}$ to $10^{-16} \mathrm{~mol} \mathrm{~L}^{-1}$ ) suggesting that the process controlling sorption at extremely low concentrations is the same as at higher concentrations.

- The desoption behavior of the bentonite and montmorillonite are very similar, indicating that, as with the adsorption experiments, the same processes are responsible for the desorption of Pu from the two materials. 


\section{ACKNOWLEDGEMENTS}

This work was supported by the Used Fuel Disposition Campaign of the Department of Energy's Nuclear Energy Program. This work was also supported by the Subsurface Biogeochemical Research Program of the U.S. Department of Energy's Office of Biological and Environmental Research. Prepared by LLNL under Contract DE-AC52-07NA27344.

\section{REFERENCES}

1. Sánchez, L.; Cuevas, J.; Ramírez, S.; Riuiz De León, D.; Fernández, R.; Vigil Dela Villa, R.; Leguey, S., Reaction kinetics of FEBEX bentonite in hyperalkaline conditions resembling the cementbentonite interface. Applied Clay Science 2006, 33, (2), 125-141.

2. Begg, J. D.; Zavarin, M.; Zhao, P.; Tumey, S. J.; Powell, B.; Kersting, A. B., Pu(V) and Pu(IV) Sorption to Montmorillonite. Environ Sci Technol 2013, 47, (10), 5146-5153.

3. Zavarin, M.; Powell, B. A.; Bourbin, M.; Zhao, P. H.; Kersting, A. B., $\mathrm{Np}(\mathrm{V})$ and $\mathrm{Pu}(\mathrm{V})$ ion exchange and surface-mediated reduction mechanisms on montmorillonite. Environ Sci Technol 2012, 46, (5), 2692-2698.

4. $\quad$ Powell, B. A.; Duff, M. C.; Kaplan, D. I.; Fjeld, R. A.; Newville, M.; Hunter, D. B.; Bertsch, P. M.; Coates, J. T.; Eng, P.; Rivers, M. L.; Sutton, S. R.; Triay, I. R.; Vaniman, D. T., Plutonium oxidation and subsequent reduction by Mn(IV) minerals in Yucca Mountain tuff. Environ Sci Technol 2006, 40, (11), 3508-3514. 